\title{
AN UNUSUAL TRICUSPID CHONDRICHTHYAN TOOTH FROM THE LOWER PERMIAN OF TEXAS, USA.
}

\author{
GARY D. JOHNSON \\ Department of Earth Sciences, University of South Dakota, 414 East Clark St., Vermillion, SD 57069, U.S.A. \\ gjohnson@usd.edu
}

\begin{abstract}
A single small, well-preserved complete tooth from the upper Petrolia Formation (early Artinskian), Wichita Group, in north-central Texas, possesses a crown composed of three nearly parallel labially-positioned principal cusps of about equal length and stature. Secondary cusps are absent. The lateral cusps are nearly straight and cylindrical, but proximally compressed; they each bear about nine mostly straight cristae on all margins, mostly restricted to the distal half. The central cusp is similar, although less compressed, and bears about seven cristae with none on the lingual side. The base is longer than wide (labial-lingual) and possesses a similarly elongated basal tubercle and apical button. The basal tubercle is slightly concave, restricted to the labial half of the aboral surface, and has a prominent labial rim which is indented. The prominent apical button covers the oral surface of the lingually extended base, lies partly between the lateral cusps, is in contact with all three cusps, and its lingual margin bears prominent centrally positioned foramina, resulting in a slightly bifurcated appearance. These characters are similar in some aspects to the Late Devonian phoebodontiforms Phoebodus politus and Jalodus. Among xenacanthiform sharks, the tooth is most similar to Bransonella from the Carboniferous and Early Permian (Asselian). The Texas Permian tooth shows no evidence of wear from transport. It probably represents a new taxon, and its morphology supports the concept that phoebodontiforms and xenacanthiforms are closely related. The shapes of the apical button and basal tubercle, and especially the three equal cusps, suggest this tooth may be allied more closely to the phoebodontiforms, but its affinity cannot presently be determined.
\end{abstract}

Key words: Phoebodontiforms, xenacanths, chondrichthyans, Lower Permian, Texas.

RESUMO - Um único pequeno dente, completo e bem preservado, proveniente da parte superior da Formação Petrolia (Artinskiano inferior), Grupo Wichita, no norte-centro do Texas, possui uma coroa composta de tres cúspides principais quase paralelas, de posição labial e comprimento e estatura iguais. Cúspides secundárias estão ausentes. As cúspides laterais são quase retas e cilíndricas, mas proximalmente comprimidas; cada uma possui cerca de nove cristas quase retas em todas as margens, quase todas restritas à metade distal. A cúspide central é similar, embora menos comprimida e possui sete cristas, nenhuma na face lingual. A base é mais longa que larga (labial-lingualmente) e possui similarmente alongados tubúrculo basal e botão apical. $\mathrm{O}$ tubérculo basal é ligeiramente côncavo, restrito à metade labial da superfície aboral e tem uma prominente borda labial que é indentada. O botão apical prominente cobre a superfície oral da base que se extende lingualmente, situa-se parcialmente entre as cúspides laterais, está em contato com todas as tres cúspides e sua margem lingual possui forames proeminentes, centralmente distribuidos, o que resulta em uma aparência ligeiramente bifurcada. Estas características são similares, em alguns aspectos, àquelas dos foebodontiformes Phoebodus politus e Jalodus do final do Devoniano. Dentre os tubarões xenacanthiformes, o dente mais se parece com o de Bransonella do Carbonífero e Permiano Inferior (Asseliano). O dente do Permiano do Texas não apresenta sinais de desgaste por transporte. Ele provavelmente representa um novo taxon e sua morfologia dá suporte ao conceito que phoebodontiformes e xenacanthiformes são proximamente relacionaodos. As formas do botão apical e tubérculo basal e especialmente as tres cúspides iguais, sugerem que este dente possa estar mais proximamente aliado aos phoebodontiformes, mas sua afinidade não pode ser determinada no presente.

Palavras-chave: Febodontiformes, xenacantídeos, condrictes, Permiano Inferior, Texas. 